\title{
The efficacy of neurotropin in treating patients with nummular headaches
}

\author{
D Danno ${ }^{*}$, H Tachibana \\ From The European Headache and Migraine Trust International Congress \\ London, UK. 20-23 September 2012
}

\section{Introduction}

A nummular headache is a headache that is characterized by pain localized to a small, circumscribed area of the head, typically measuring 2 to $6 \mathrm{~cm}$ in diameter in the absence of any lesion of the underlying structures.

\section{Purpose}

Neurotropin is a non-protein extract isolated from the inflamed skin of rabbits inoculated with the vaccinia virus that is used to treat neuropathic pain. In this study, we reviewed three cases retrospectively to assess the possible efficacy of neurotropin in patients with nummular headaches.

\section{Methods}

Three nummular headache patients participated in this study. For each patient, the diagnosis of nummular headache was made based on the ICHD - II nummular headache diagnostic criteria. We prescribed neurotropin at a dose of $16 \mathrm{NU} /$ day to the patients during the clinical course of this study.

\section{Results}

Case 1: A 39-year-old male developed bifocal pain one week previously in a circumscribed area of the left temporal region measuring $4 \mathrm{~cm}$ in diameter. Treatment with NSAIDs was determined to be invalid. Treatment with neurotropin relieved the patient's pain, and the headache resolved after four days. Case 2: A 57-year-old female developed bifocal pain one week previously in a circumscribed area including both temporal regions measuring $3 \mathrm{~cm}$ in diameter. Treatment with neurotropin relieved the patient's pain slightly; however, the headache remained. Case 3: A 71-year-old male developed pain more than one year previously in a circumscribed area of the left parietal

\footnotetext{
Hyogo College of Medicine, Japan

\section{SpringerOpen ${ }^{\circ}$}

(C) 2013 Danno and Tachibana; licensee Springer. This is an Open Access article distributed under the terms of the Creative Commons Attribution License (http://creativecommons.org/licenses/by/2.0), which permits unrestricted use, distribution, and reproduction in any medium, provided the original work is properly cited. region measuring $3 \mathrm{~cm}$ in diameter. Treatment with NSAIDs was determined to be invalid. Treatment with neurotropin relieved the patient's pain, and the headache resolved after three months. In two of the three cases of patients with nummular headaches, treatment with neurotropin was found to be very effective for pain reduction.

\section{Conclusion}

The present results suggest that prescribing neurotropin may be a possible choice for treating patients with nummular headaches.

Published: 21 February 2013

\section{References}

1. Pareja JA, Caminero AB, Serra J, Barriga FJ, Dobato JL, Barón M, Vela L, Sánchez del Río M: Numular headache: a coin-shaped cephalgia. Neurology 2002, 58:1678-1679.

2. Hata $T$, Kita $T$, Itoh E, Oyama R, Kawabata A: Mechanism of the analgesic effect of neurotropin. Jpn J Pharmacol 1988, 48:165-73.

Cite this article as: Danno and Tachibana: The efficacy of neurotropin in treating patients with nummular headaches. The Journal of Headache and Pain 2013 14(Suppl 1):P40.

Submit your manuscript to a SpringerOpen ${ }^{\bullet}$ journal and benefit from:

- Convenient online submission

- Rigorous peer review

- Immediate publication on acceptance

- Open access: articles freely available online

- High visibility within the field

- Retaining the copyright to your article

Submit your next manuscript at $>$ springeropen.com
doi:10.1186/1129-2377-14-S1-P40 \section{(1)}

